\title{
RUBBER CONTACT DERMATITIS IN PATIENTS ATTENDED AT WALTER CANTÍDIO HOSPITAL, FEDERAL UNIVERSITY OF CEARÁ, BRASIL
}

\author{
Maria José N. DIÓGENES, Océlia B. VERAS, Raquel M. de MORAIS \& Tereza Elizabeth F. MEIRELES
}

\begin{abstract}
SUMMARY
Nowadays $70 \%$ of the world's rubber supply is synthesized artificially. The process involved in its manufacture is vulcanization which requires many chemical substances for speeding the process, as antioxidants to prevent deterioration of rubber, or others. These substances may constitute important sensitizers and thus be responsible for dermatological diseases like contact dermatitis. The objective of this study is to search for the main sensitizers among these rubber chemicals in a population mostly composed by women of a tropical country and compare the results with the ones obtained from previous studies which tested populations mainly composed by men and on different climates.
\end{abstract}

KEYWORDS: Contact dermatitis; Rubber chemicals.

\section{INTRODUCTION}

Rubber is an organic substance obtained from natural sources or synthesized artificially. Ninety nine percent of natural rubber, latex, is obtained from the Hevea brasiliensis tree. Latex has been responsible for anaphylactic contact allergic reactions that occur frequently in atopics with hand eczemas and paraplegics in use of plummets in genital-urinary $\operatorname{tract}^{9}$. Today $70 \%$ of the world's rubber supply is synthesized artificially. This rubber contains more than two thousand different chemicals and some of them may cause contact dermatitis ${ }^{4}$ which occur more frequently in people who use and/or wear rubber objects than in people who work with its manufacture. It is also reported allergy to surgeons' gloves in their patients ${ }^{1}$. Among these objects, gloves and shoes $2,8,10$ are the most common; probably because of the heat and humidity found in those regions that appear to be predisponent factors. Substances with chemical composition similar to products used in rubber industrialization found in clothes ${ }^{6}$, drugs, paint and fungicides, may crossreact with rubber representing an additional factor for sensitization ${ }^{5}$.

The most comprehensive recent review of rubber allergy was undertaken by CONDE-SALAZAR et al. (1993) ${ }^{3}$. It points out rubber components as the second main cause of contact dermatitis. Among these components tetramethyl- thiuram disulphide and mercaptobenzothiazole stood out as the main sensitizers. The tested group was composed by 3264 men and 1416 women. Almost half of the positive cases were male construction workers who wear protecting rubber gloves and boots ${ }^{3}$.

Considering the existence of very few studies about this matter in tropical countries, the objective of this review was to determine the occurrence of rubber contact dermatitis, its distribution between sexes and, among its chemical compounds, the main sensitizers in patients attended at the Walter Cantídio Hospital - Federal University of Ceará (the only public service that attends contact dermatitis in this area).

\section{PATIENTS AND METHODS}

Four hundred and forty two patients (98 men and 344 women) with clinical diagnosis of contact dermatitis were submitted to the contact test or "patch-test" with a standard and complementary battery (ALERBRÁS laboratory, Rio de Janeiro, Brazil) composed of 51 substances on the period of two years. The tests were applied at the back of the patients. It was established 48 and 96 hours to determine the reaction degree according to standards of International Contact Dermatitis Research Group (ICDRG).

Correspondence to: Maria José N. Diógenes, Departamento de Medicina Clínica, Universidade Federal do Ceará, Rua Monsenhor Bruno 630/502, 60115-190 Fortaleza, Ceará, Brazil. Fax: 55.85.2617618 
DIÓGENES, M. J. N.; VERAS, O. B.; MORAIS, R. M. de \& MEIRELES, T. E. F. - Rubber contact dermatitis in patients attended at Walter Cantídio Hospital, Federal University of Ceará, Brasil. Rev. Inst. Med. trop. S. Paulo, 40(2): 101-103, 1998.

\section{RESULTS}

The group tested was composed of 344 women $(77.83 \%)$ and 98 men $(22.17 \%)$. There were $402(90.95 \%)$ positive and $40(9.05 \%)$ negative tests to one of the 51 components of the battery used. Table 1 shows the percentage of positive patch tests. Only 11 compounds were significant as sensitizers; the other 40 were put together as "others" on Table 1 .

TABLE 1

Frequency of positive patch tests of different compounds of the battery used among all tests that were made. Dermatological Service, Walter Cantídio University Hospital, Federal University of Ceará, 1993-1994.

\begin{tabular}{lcc}
\hline Component & Absolute number & Frequency \\
\hline Nickel sulphate & 57 & $12.9 \%$ \\
Rubber chemicals & 46 & $10.5 \%$ \\
Thimerosol & 44 & $10.0 \%$ \\
Potassium bichromate & 39 & $8.8 \%$ \\
Cobalt chloride & 26 & $5.9 \%$ \\
Nitrofurazone & 24 & $5.4 \%$ \\
Quartenium & 15 & $3.4 \%$ \\
Neomicine & 11 & $2.4 \%$ \\
Mercury chloride & 11 & $2.4 \%$ \\
Eugenol & 10 & $2.3 \%$ \\
Commercial mercury & 10 & $2.3 \%$ \\
Others (< 2\%) & 109 & $24.7 \%$ \\
Negative tests & 40 & $9.0 \%$ \\
\hline Total & 442 & $100 \%$ \\
\hline
\end{tabular}

Of all tested patients $46(10.4 \%)$ were sensitized to one of the five rubber components quoted. It is observed that rubber chemicals were the second major cause of contact dermatitis. Table 2 points out the frequency of positive results among the rubber components included. P-phenylenediamine, mercaptobenzothiazole, hydroquinone and tetramethylthiuram disulphide stood out as the main sensitizers.

TABLE 2

Frequency of positive results among rubber chemicals included. Dermatological Service, Walter Cantídio University Hospital, Federal University of Ceará, 1993-1994.

\begin{tabular}{lcc}
\hline Rubber chemical & Absolute number & Frequency \\
\hline Paraphenylenediamine & 14 & $29.4 \%$ \\
Mercaptobenzothiazole & 9 & $25.9 \%$ \\
Hydroquinone & 7 & $19.6 \%$ \\
Tetramethylthiuram disulphide & 4 & $15.7 \%$ \\
Diphenylguanidine & 12 & $9.8 \%$ \\
\hline Total & 46 & $100 \%$ \\
\hline
\end{tabular}

The anatomical distribution of lesions was mostly on hands and feet. Lesions due to hydroquinone were also found on forearms, face and inguinal region.

\section{DISCUSSION}

Rubber was found to be the second main cause of contact dermatitis, a result similar to the one obtained from the group tested by CONDE-SALAZAR ${ }^{3}$. P-phenylenediamine (PPD) was responsible for the highest number of cases of rubber allergy which differ from the results obtained by CONDE-SALAZAR. This difference is probably related to the tested group that was mostly composed by women $(75.57 \%)$. It is also important to point out that these women had varied professions such as hairdressers, housekeepers, dressmakers, hospital and restaurant cleaners; which expose them to contact with other P-phenylenediamine sources not related with rubber but other products such as bleaching creams $^{7}$, dress material and shampoos ${ }^{1}$. Moreover, it must be considered that insecticides, fungicides, soap and paint may have substances which cross-react with rubber components representing an additional factor for sensitization.

Finally, the hot and humid climate of Fortaleza facilitates sensitization by PPD present in clothes, cosmetics, colours and elastic bands of underwear. It is also probably responsible for the distribution of lesions because swet facilitates contact with rubber shoes, gloves and underwear. Similar considerations are valid to explain the high incidence of contact dermatitis by Hidroquinone.

In conclusion, it is emphasized the influence of the tropical climate in manifestation of rubber components contact dermatitis and the peculiarity of the population observed in relation to sex, profession and activities. This fact instigates us to accomplish other comparative studies using bigger populations and equal distribution of sexes and professions to come to more definite conclusions.

\section{RESUMO}

Dermatite de contato por borracha em pacientes atendidos no Hospital Universitário Walter Cantídio, Universidade Federal do Ceará

Atualmente, $70 \%$ do suprimento mundial de borracha é sintetizado artificialmente. O processo envolvido em sua manufatura é a vulcanização que requer muitas substâncias químicas para aceleração do processo, como antioxidantes para prevenir a deterioração da borracha ou outros. Estas substâncias podem ter potencial sensibilizante tornando-se responsáveis por afecções dermatológicas, principalmente dermatite de contato. O objetivo deste estudo é pesquisar os principais sensibilizantes dentre os componentes da borracha 
DIÓGENES, M. J. N.; VERAS, O. B.; MORAIS, R. M. de \& MEIRELES, T. E. F. - Rubber contact dermatitis in patients attended at Walter Cantídio Hospital, Federal University of Ceará, Brasil. Rev. Inst. Med. trop. S. Paulo, 40(2): 101-103, 1998.

numa população predominantemente feminina num País Tropical e comparar os resultados com os obtidos em estudos prévios que testaram populações predominantemente masculina em climas diferentes.

\section{REFERENCES}

1. ANDERSEN, K. E.; BENEZRA, C.; BURROWS, D. et al - Contact dermatitis. A review. Contact Dermatitis, 16: 55-78, 1987.

2. ARPINI, R. H. \& CHAPO, R. M. - Dermatosis provocadas por calzado de material sintético: síndrome de las botas de goma. Med. cut. ibero lat.-amer., 15: 285-292, 1987.

3. CONDE-SALAZAR, L.; DEL-RIO, E.; GUIMARAENS, D. \& GONZALEZ DOMINGO, A. - Type IV allergy to rubber additives: a 10-year study of 686 cases. J. Amer. Acad. Derm., 29: 176-180, 1993.

4. GOH. C. L. - Contact allergy to surgeons' gloves in their patients. Contact Dermatitis, 20: 223, 1989.

5. RIETSCHEL, R. \& FOWLER JR., J. F. - Allergy to rubber. In:
RIETSCHEL, R. \& FOWLER JR., J. F., ed. Fisher's contact dermatitis. 4. ed. London, Williams \& Wilkins, 1985. p. 697-752.

6. ROMAGUERA, C. \& GRIMALT, F. - Leukoderma from hydroquinone. Contact Dermatitis, 12: 183, 1985.

7. ROMAGUERA, C.; GRIMALT, F. \& LECHA, M. - Occupational purpuric textile dermatitis from formaldehyde resins. Contact Dermatitis, 7: 152-153, 1981.

8. SAGRERA, C. R.; SANCHO, F.G. \& AGUADÉ, J.P. - Nuevos alergenos, pertencientes al grupo de las resinas, en la dermatitis de contacto al calzado. Med. cut. ibero lat. amer., 2: 201-212, 1974.

9. WILKINSON. J.D. \& RYCROFT, R.J.G - Contact dermatitis. In: CHAMPION, R.H.; BURTON, J.L. \& EBLING, F.J.G., ed. Textbook of dermatology. 5. ed. Oxford, Blackwell, 1992. v. 1, p. 611-715.

10. ZAITZ, I.D.; PROENÇA, N.G.; DROSTE, D. \& GROTTI, A. Dermatite de contato acromiante por sandálias de borracha. Med. cut. ibero lat.-amer., 15: 1-7, 1987.

Recebido para publicação em 14/08/1997

Aceito para publicação em 29/12/1998 